\title{
Role of Gluten in Surface Chemistry: Nanometallic Bioconjugation of Hard, Medium, and Soft Wheat Protein
}

Divya Mandial, Poonam Khullar, Vikas Gupta, Harsh Kumar, Narpinder Singh, Gurinder Kaur Ahluwalia, Mandeep Singh Bakshi 


\section{Fig S1}

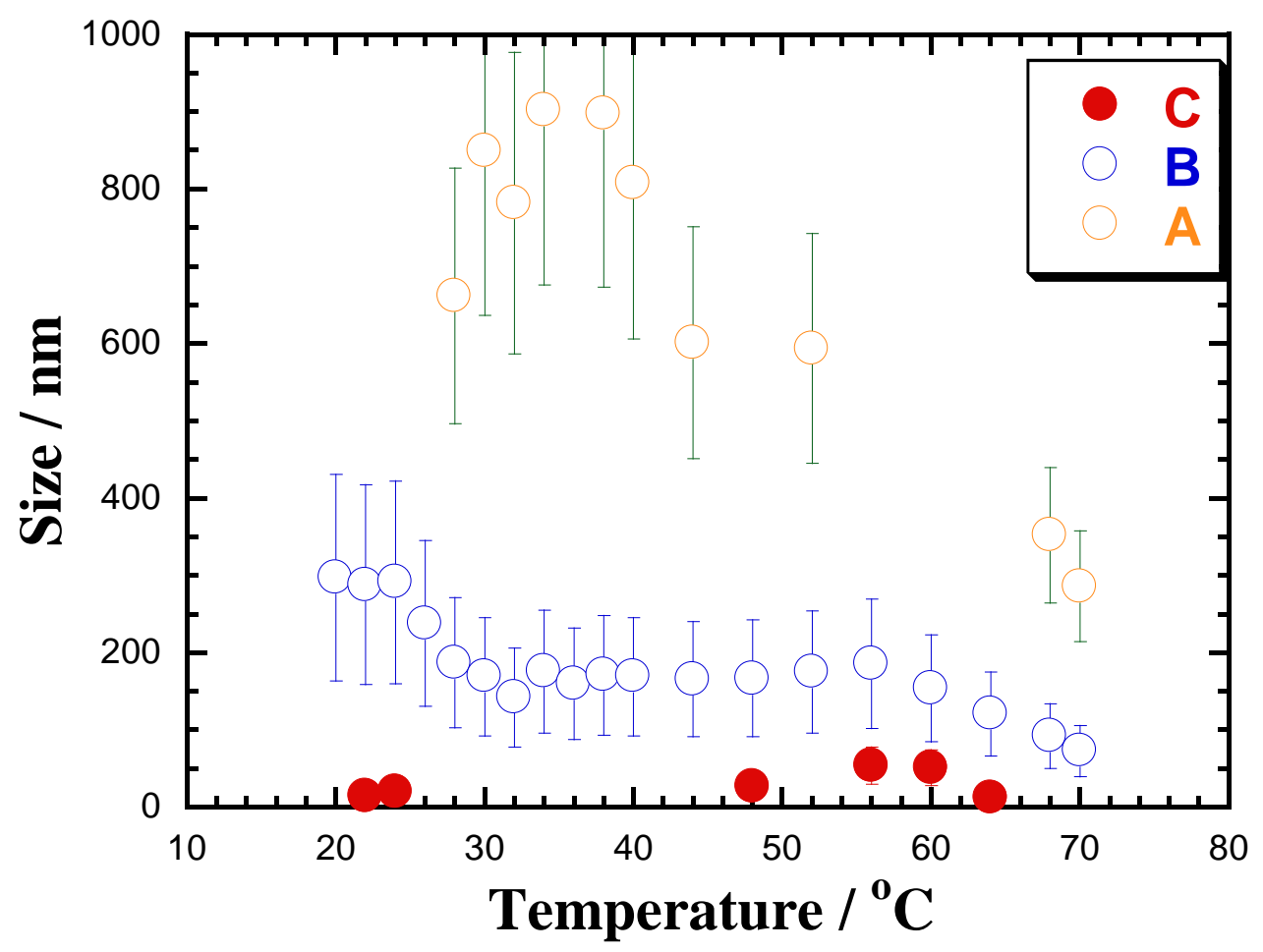

Figure S1. Size distribution histograms of aqueous solutions of CTAB solubilized hard wheat protein $1 \mathrm{mg} / 1 \mathrm{ml}$ of $10 \mathrm{mM} \mathrm{CTAB}$ solution with temperature depicting three different components of hard wheat protein. 


\section{Fig S2}

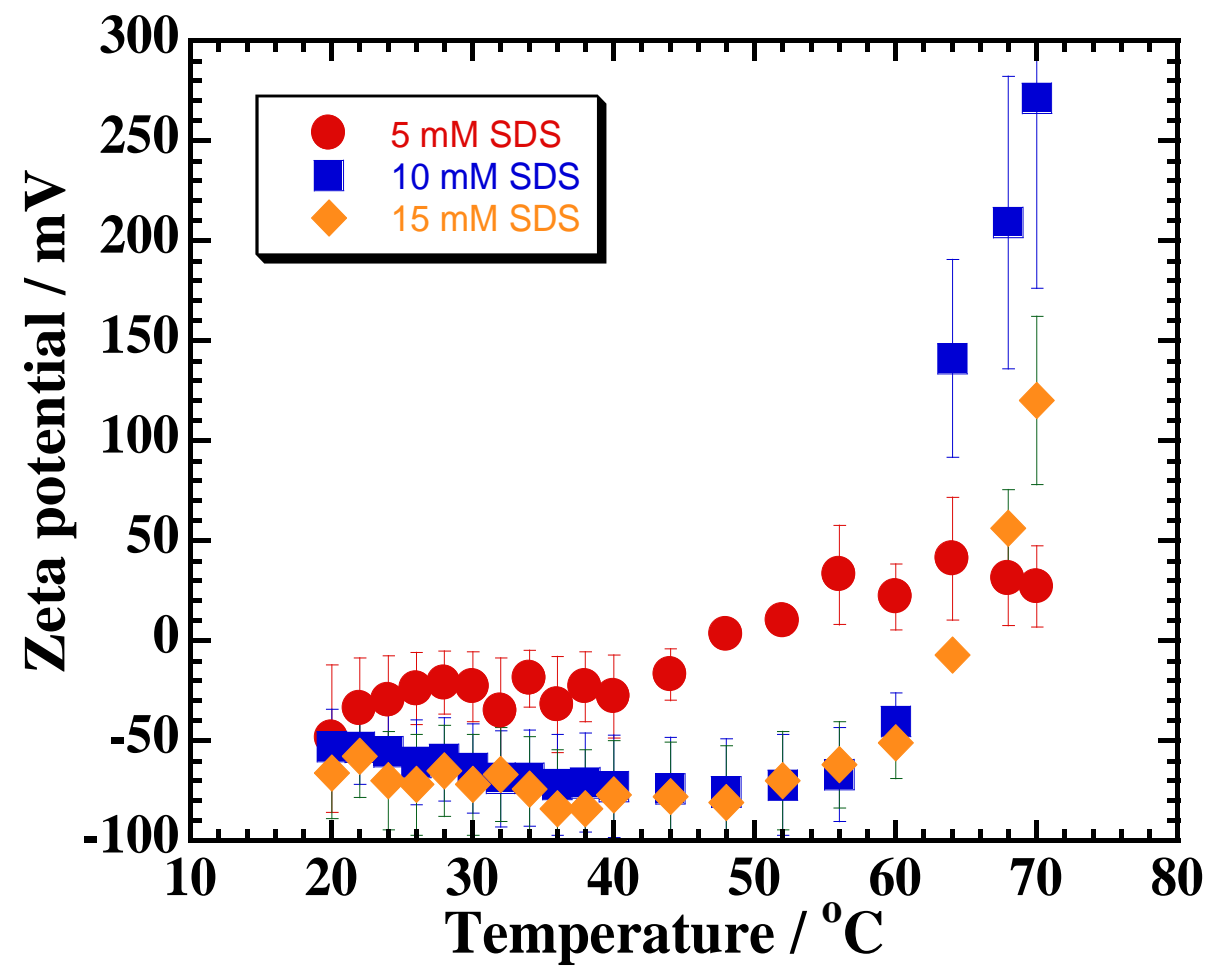

Figure S2. Zeta potential of SDS solubilized hard wheat protein at different concentrations of $\operatorname{SDS}(5,10,15 \mathrm{mM})$. 


\section{Fig S3}

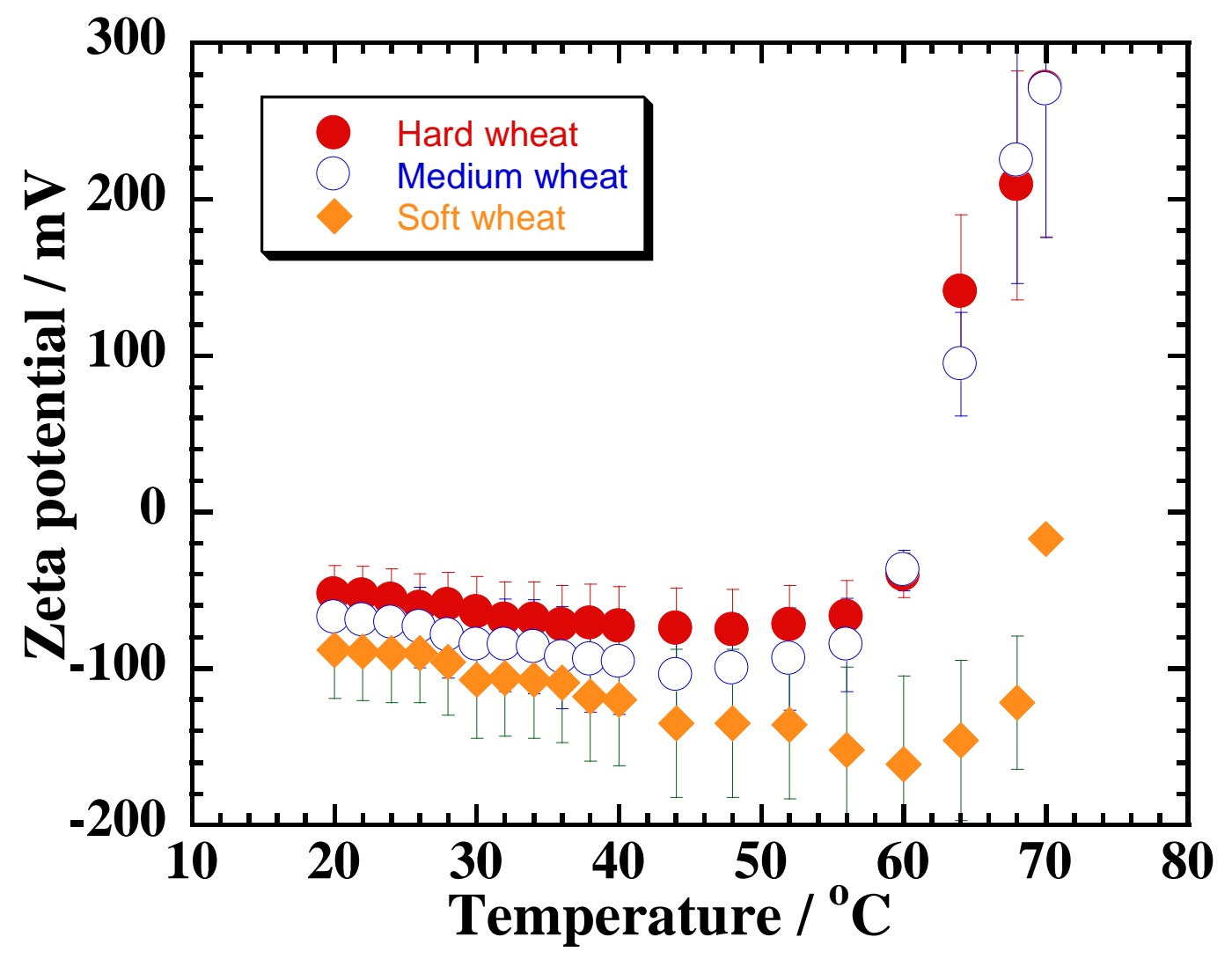

Figure S3. Comparative zeta potential plots of SDS solubilized hard, medium, soft wheat proteins at same concentration. 


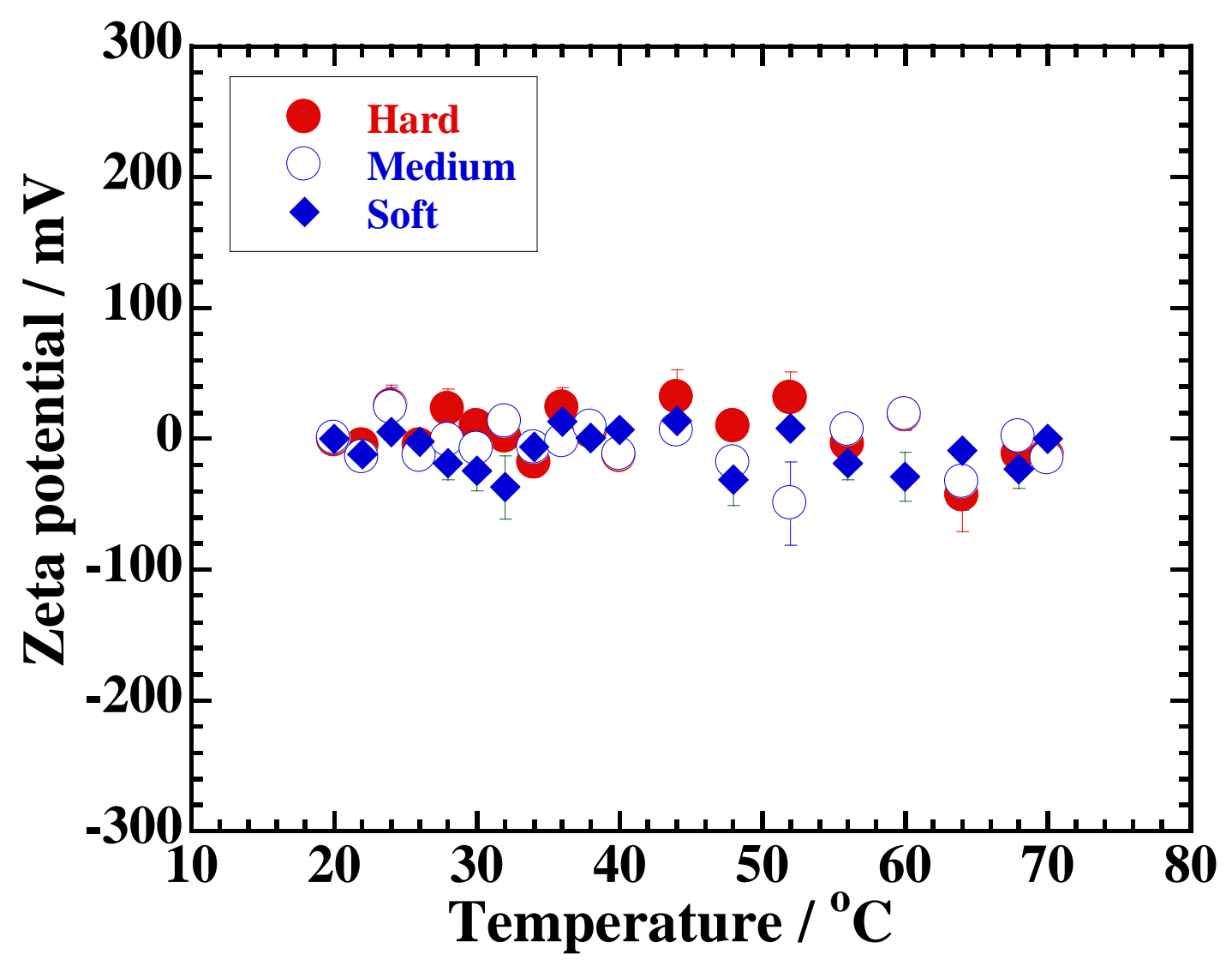

Figure S4. Comparative zeta potential plots of SDS solubilized hard, medium, soft wheat proteins in basic medium and in the absence of surfactants. 


\section{Fig S5}

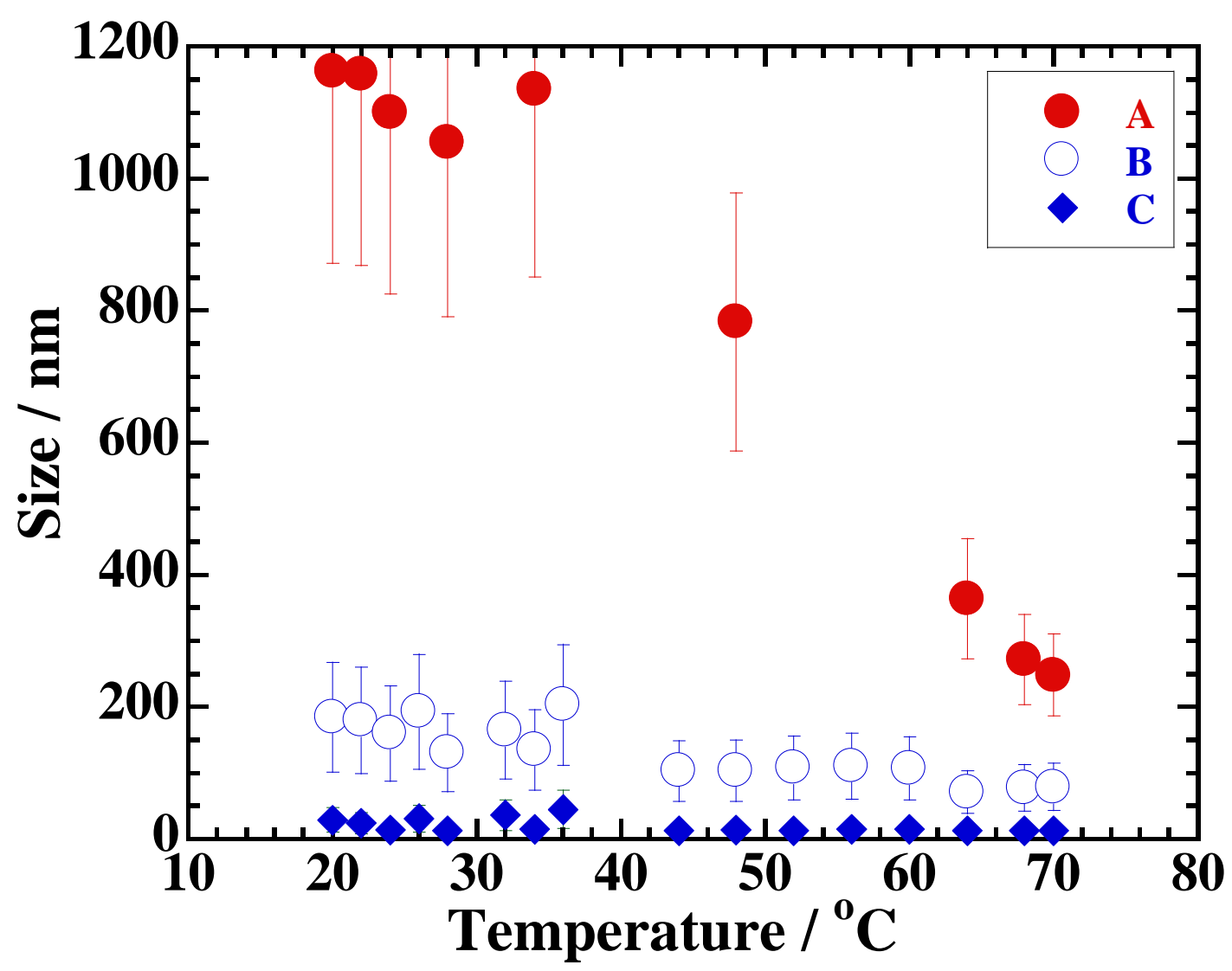

Figure S5. Comparative DLS size distribution plots of SDS solubilized hard, medium, soft wheat proteins in basic medium and in the absence of surfactants. 


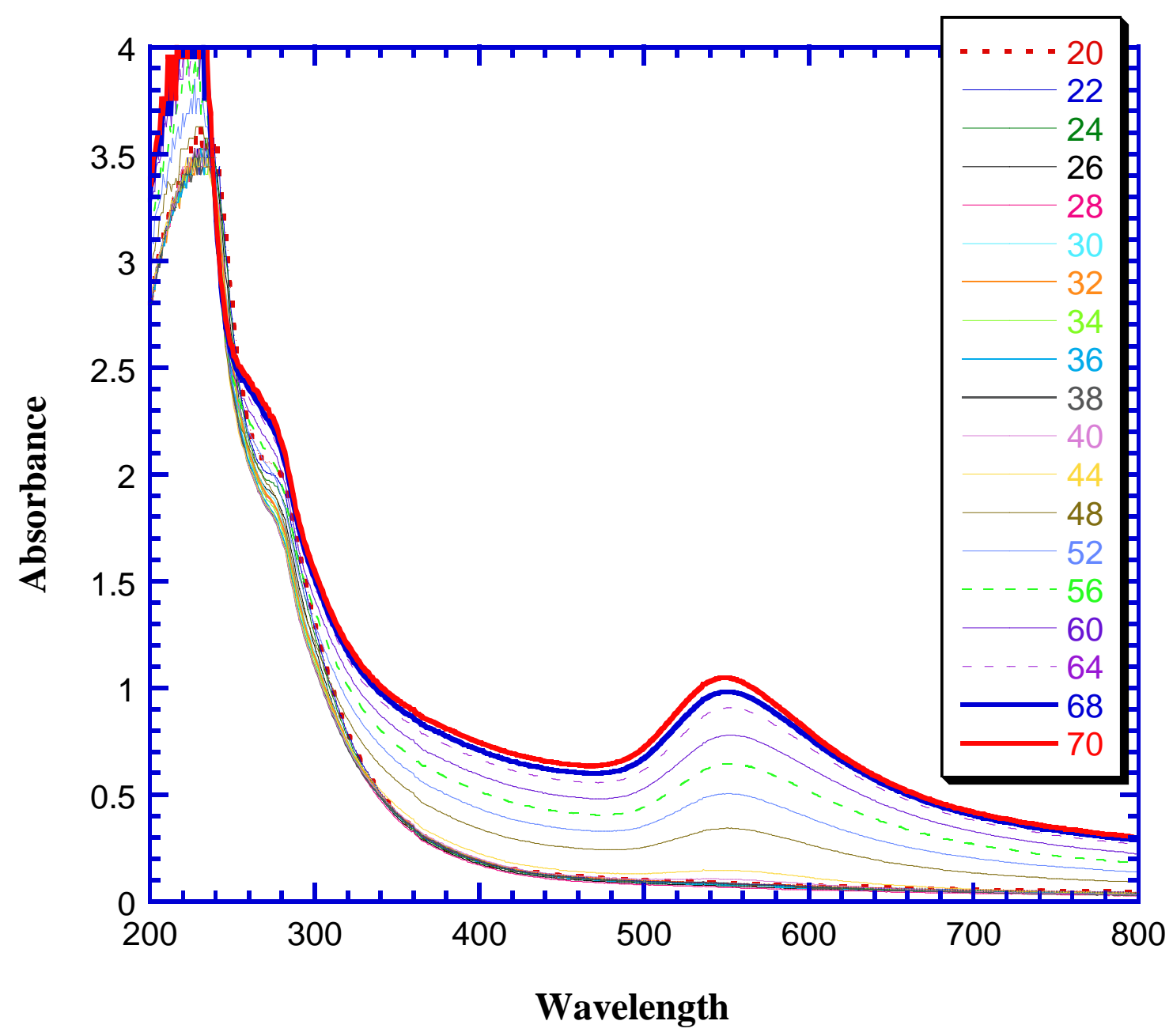

Figure S6. UV- Visible scan of a typical reduction of $\mathrm{Au}(\mathrm{III})$ into $\mathrm{Au}(0)$ by using SDS solublized medium wheat protein. 


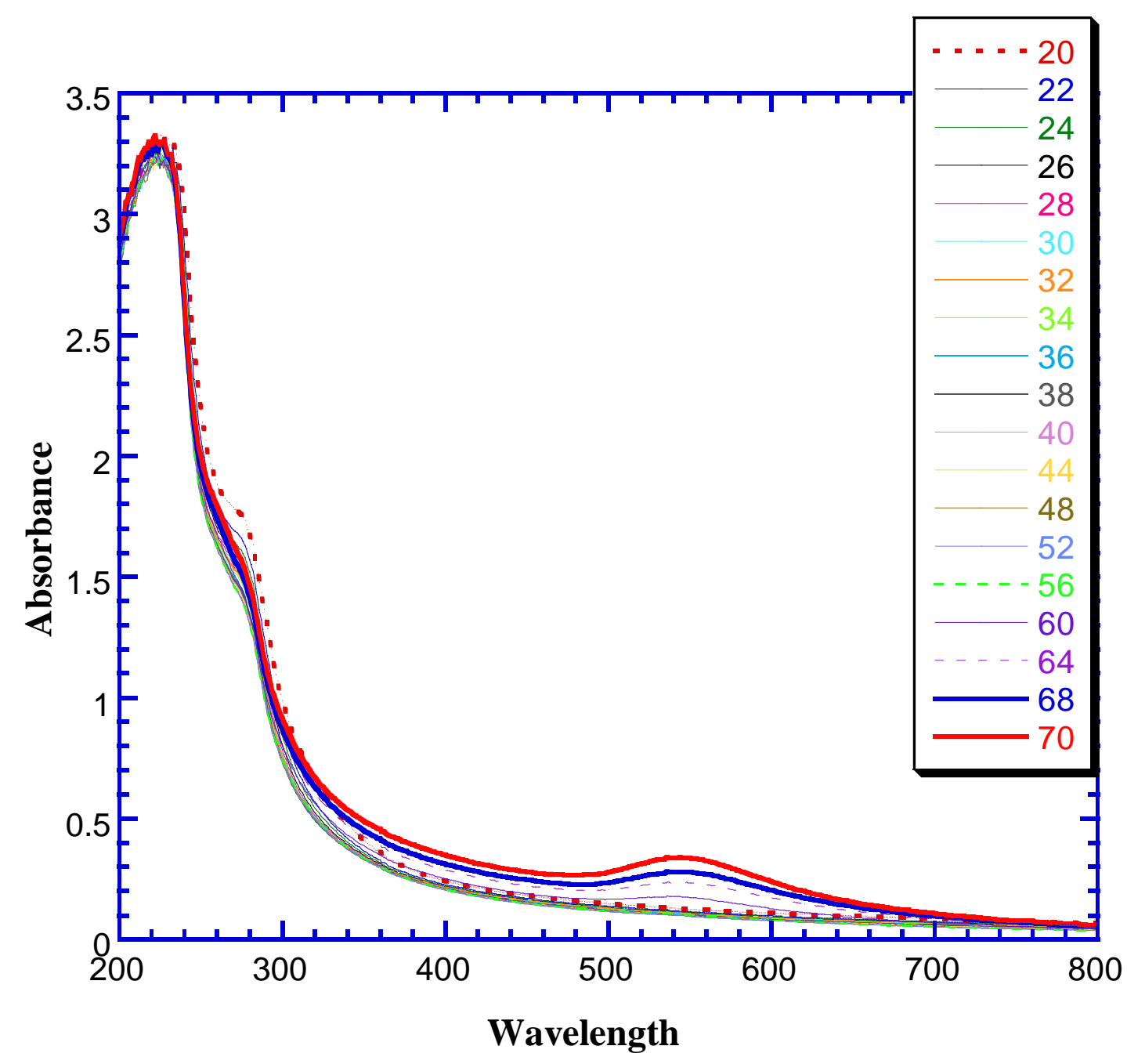

Figure S7. UV- Visible scan of a typical reduction of $\mathrm{Au}(\mathrm{III})$ into $\mathrm{Au}(0)$ by using SDS solublized soft wheat protein. See details in the text. 


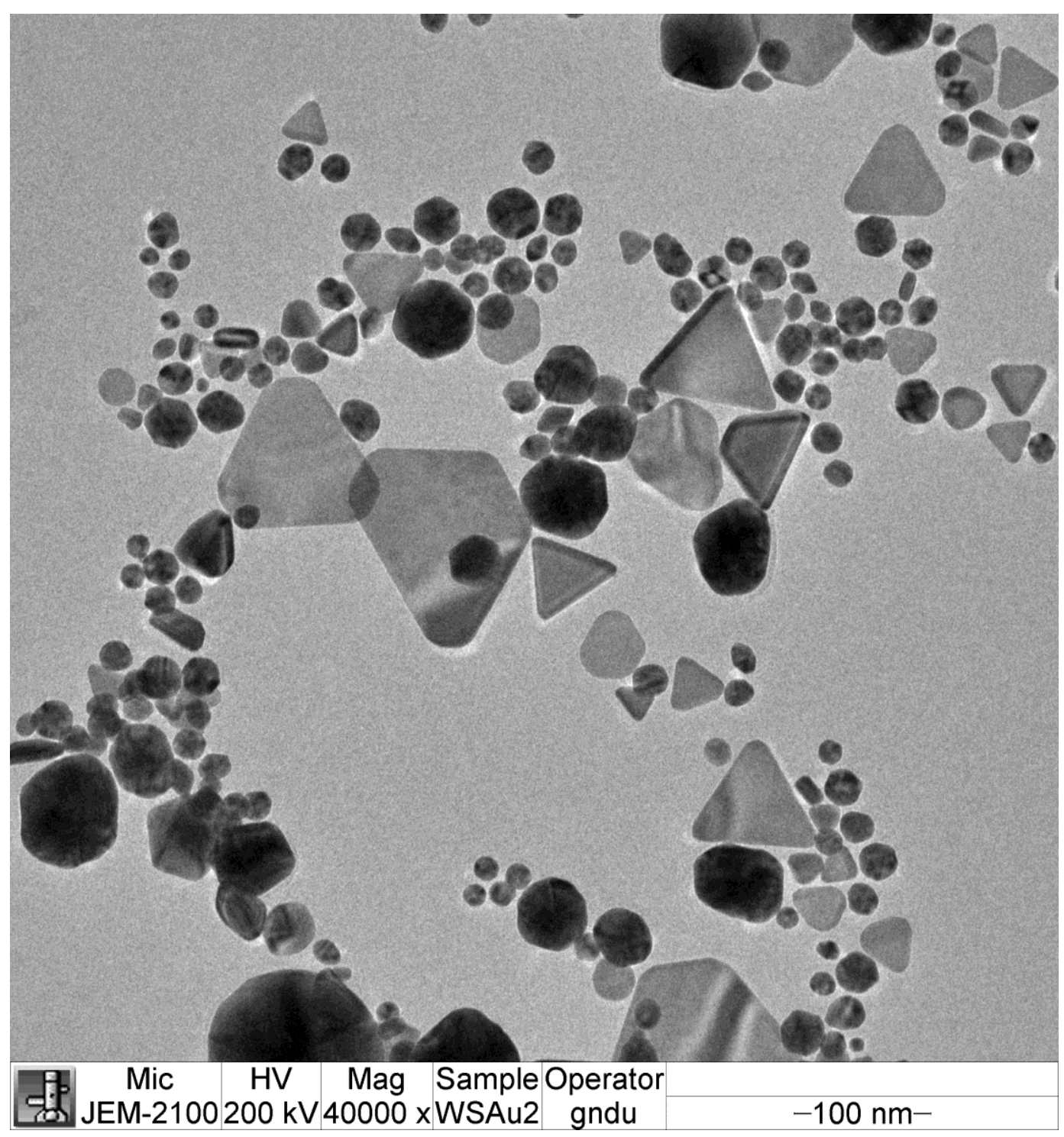

Fig S8

Figure S8. TEM images of Au NPs synthesized from SDS solubilized medium wheat protein. 


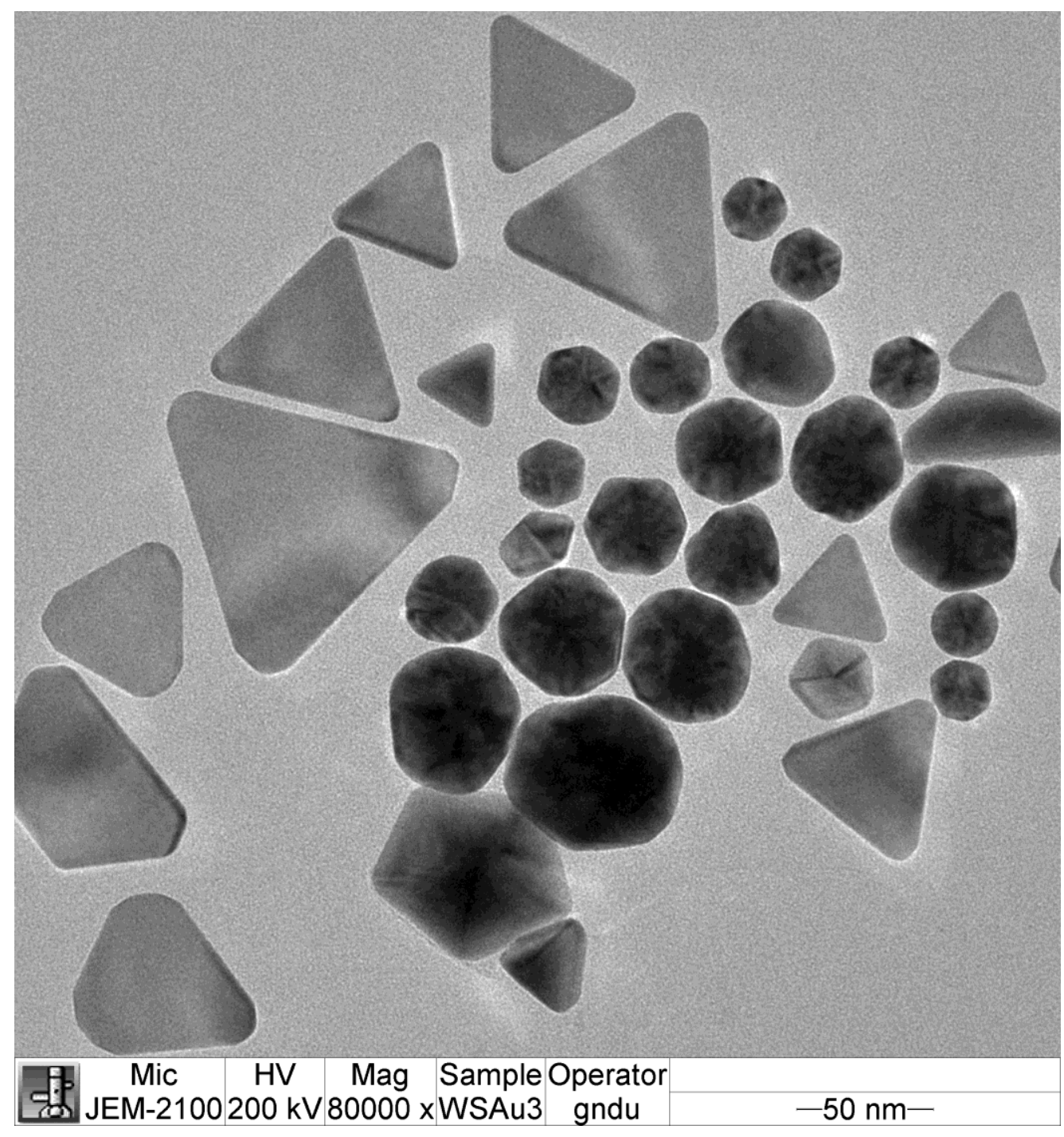

Fig S9

Figure S9. TEM images of Au NPs synthesized from SDS solubilized soft wheat protein. 


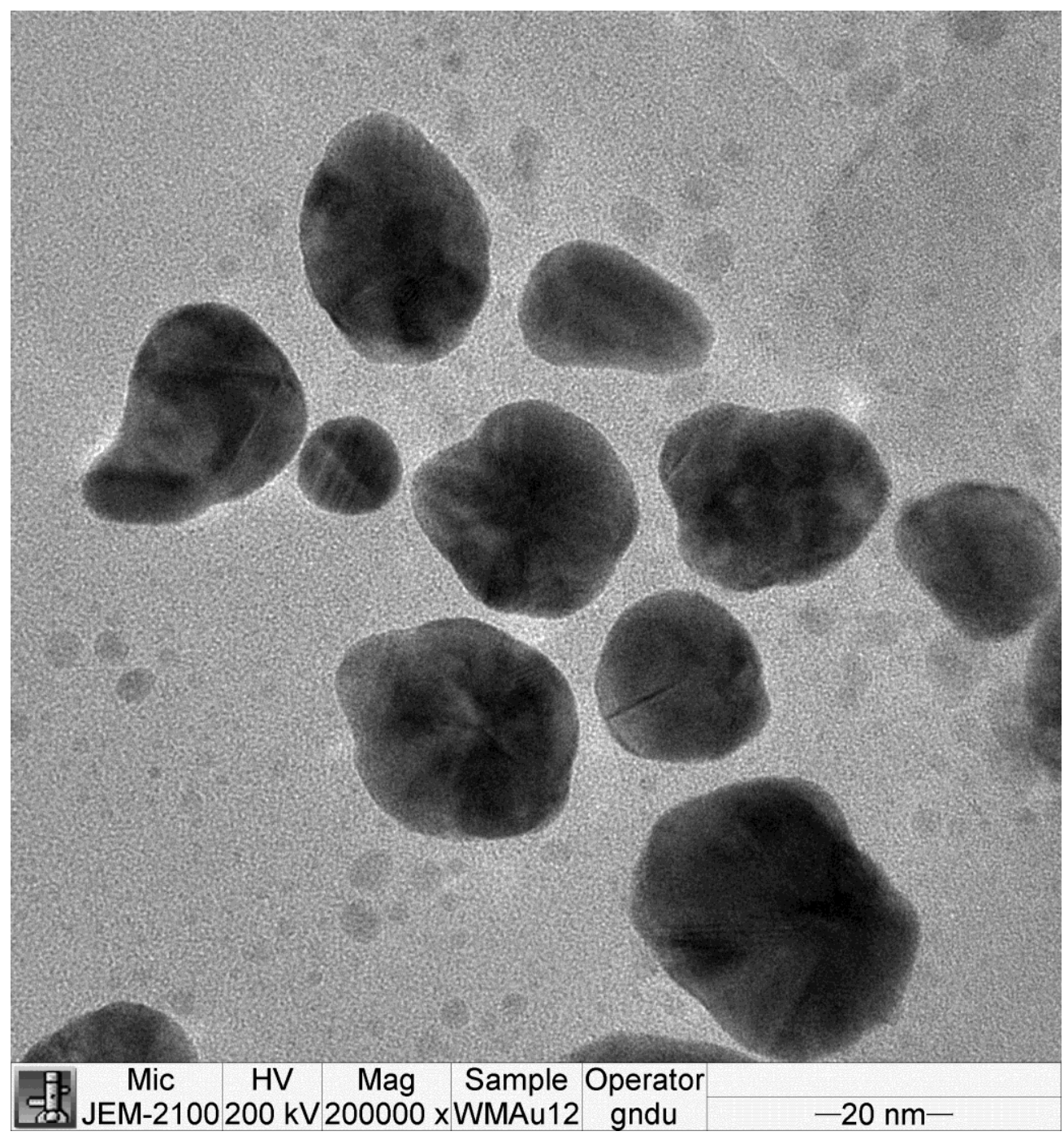

Fig S10

Figure S10. TEM images of Au NPs synthesized from CTAB solubilized medium wheat protein. 


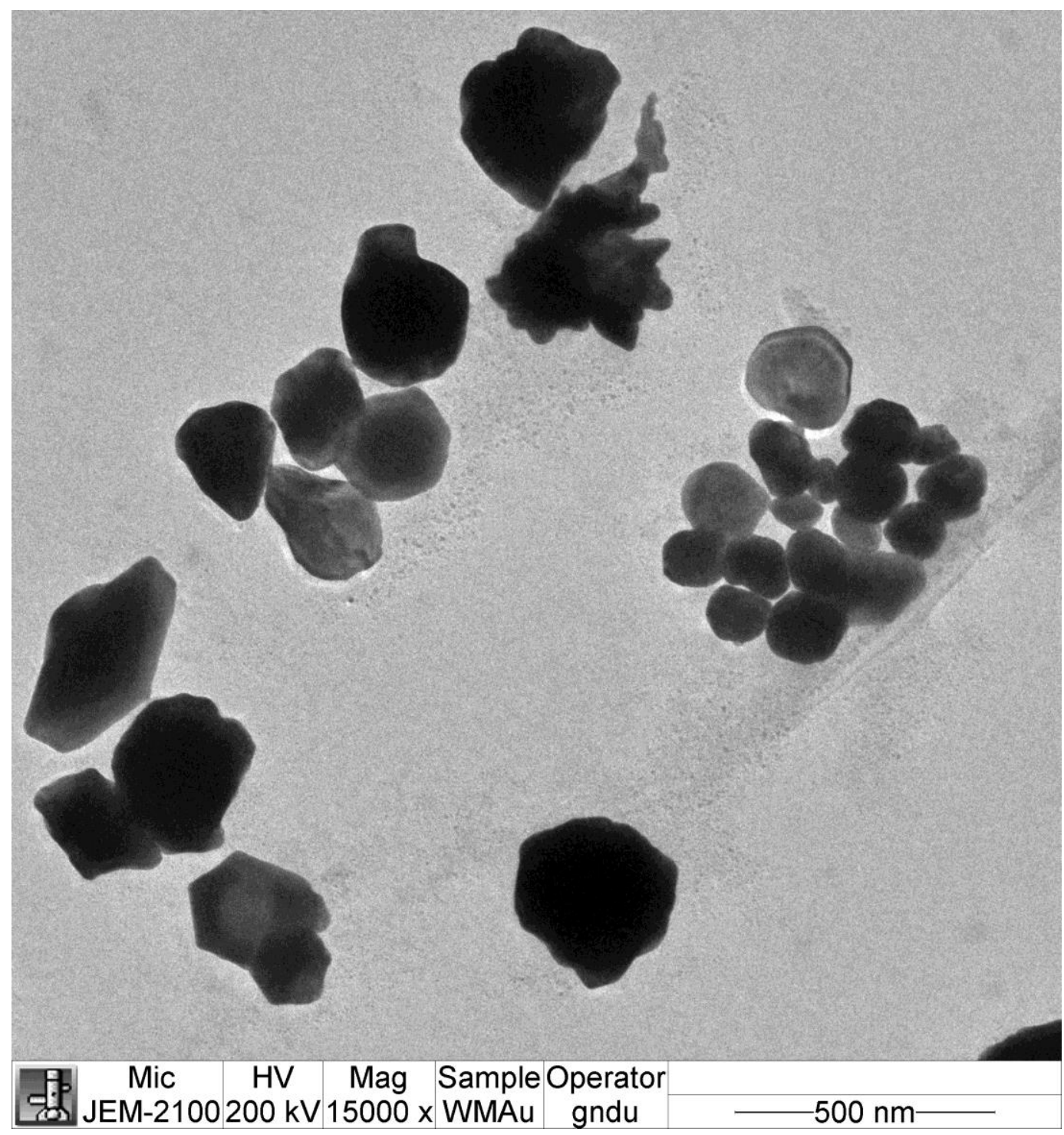

Fig S11

Figure S11. TEM images of AuNPs synthesized from CTAB solubilized soft wheat protein. 
Fig S12
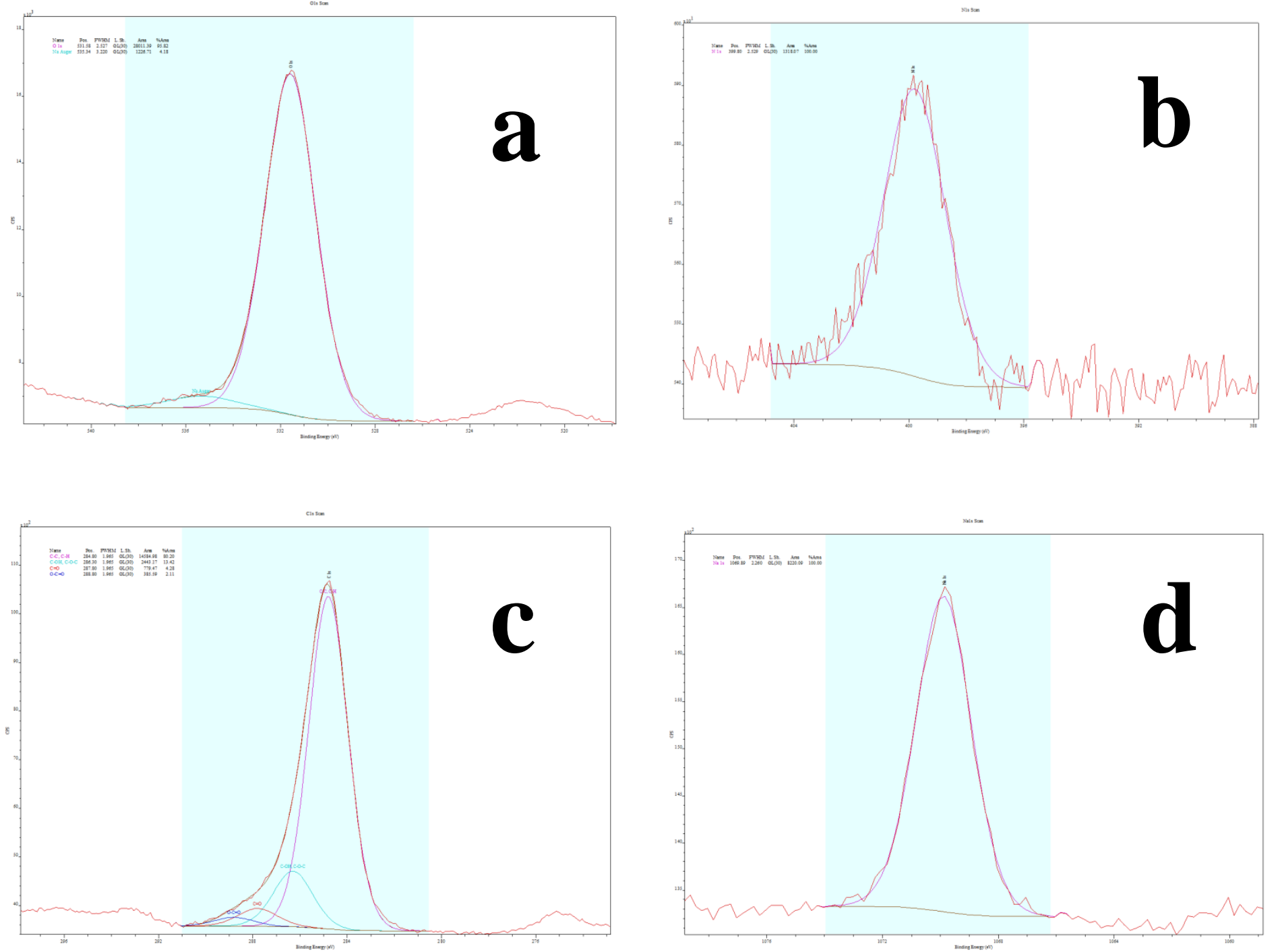


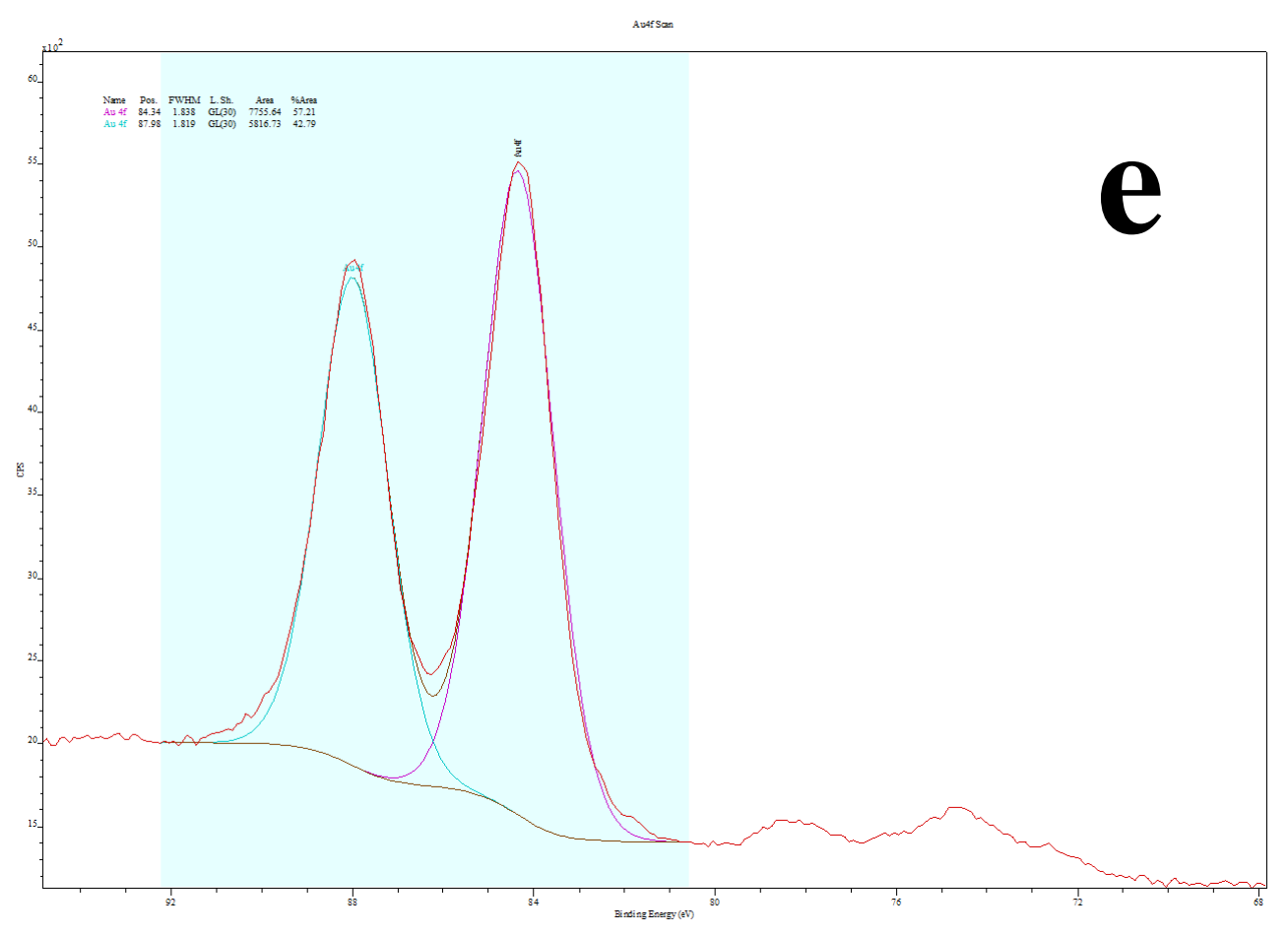

Figure S12. XPS analysis of O-1S (a), N-1s (b), Na-1s (c), C-1S (d), and Au4F (e) SDS solubilized hard wheat protein coated Au NPs. 


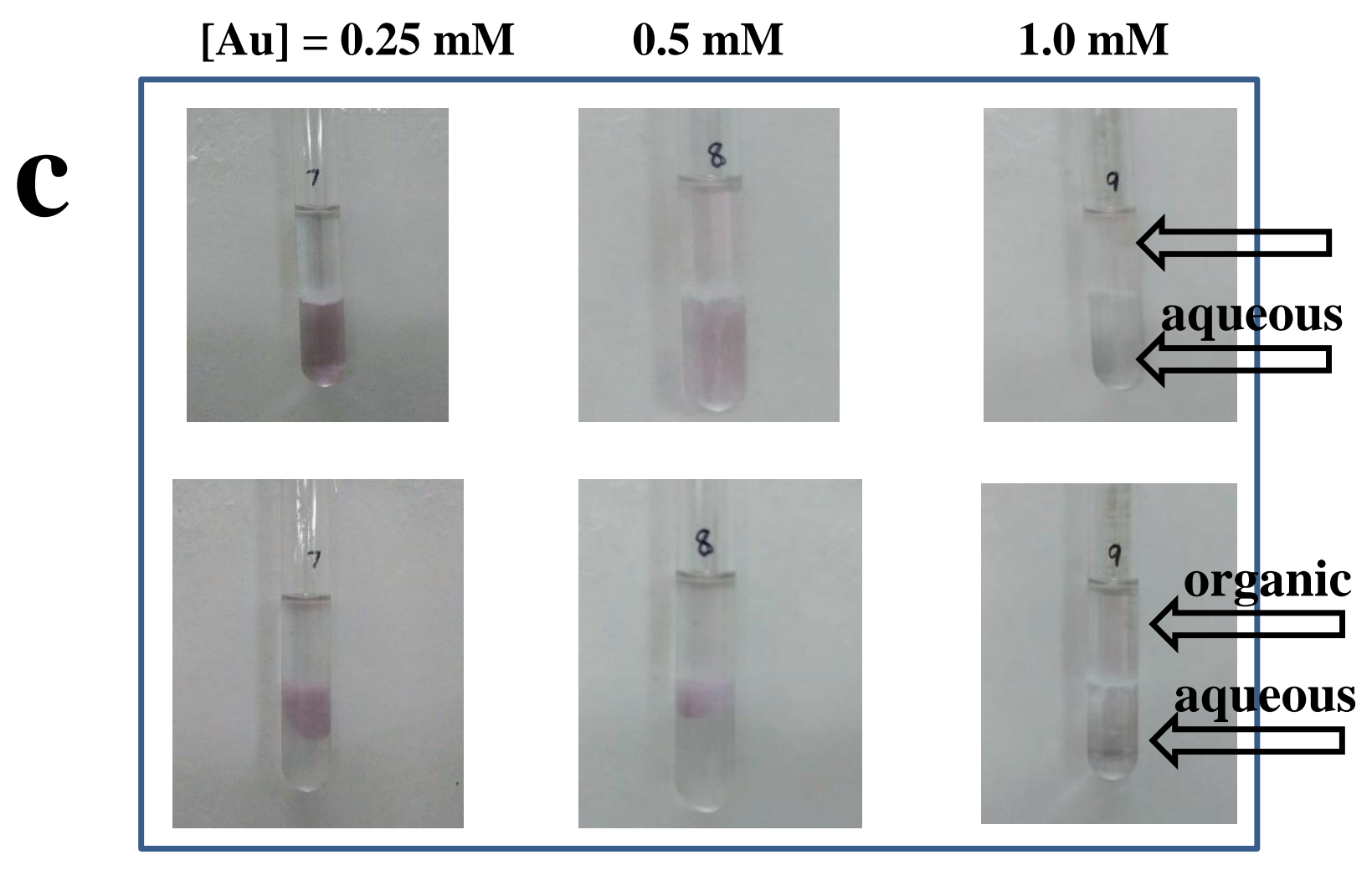

Figure S13. Images of sample tubes labeled \# $1-9$ depicting the phase transfer of CTAB solubilized hard (a, 1, 2, 3), medium $(\mathbf{b}, 4,5,6)$, and soft $(\mathbf{c}, 7,8,9)$ wheat protein $(1 \mathrm{mg} / 1 \mathrm{ml}$ of $10 \mathrm{mM} \mathrm{CTAB}$ ) conjugated Au NPs synthesized by using different concentrations of gold salt $(0.25,0.50,1.0 \mathrm{mM})$ across the aqueous - organic interface. In figures $\mathbf{a}-\mathbf{c}$, the upper panel sample images are before the phase transfer and lower panel represents the images after the phase transfer. 
\begin{tabular}{|llll|}
\hline $\begin{array}{llll}\text { Hard wheat } \\
\text { SDS (control) }\end{array}$ & Au1 & Au2 & Au3
\end{tabular}$\quad$ Fig S14

a

$98 \mathrm{kDa}$

$93 \mathrm{kDa}$

$89 \mathrm{kDa}$

$85 \mathrm{kDa}$
$78 \mathrm{kDa}$

$78 \mathrm{kDa}$
$74 \mathrm{kDa}$

$85 \mathrm{kDa} \longrightarrow$

$85 \mathrm{kDa} \longrightarrow$

$85 \mathrm{kDa} \longrightarrow$

$71 \mathrm{kDa}$

$71 \mathrm{kDa}=$

$54 \mathrm{kDa}$

$52 \mathrm{kDa}$

$74 \mathrm{kDa} \longrightarrow$

$74 \mathrm{kDa} \longrightarrow$

$74 \mathrm{kDa} \longrightarrow$

Medium wheat

SDS (control)

Au1

Au2

Au3

$98 \mathrm{kDa} \longrightarrow$

$93 \mathrm{kDa} \longrightarrow$
$89 \mathrm{kDa} \longrightarrow$

$85 \mathrm{kDa}$

$78 \mathrm{kDa} \longrightarrow$

$74 \mathrm{kDa}$

$71 \mathrm{kDa}$

$56 \mathrm{kDa}$

$52 \mathrm{kDa}$

$45 \mathrm{kDa} \longrightarrow$
$85 \mathrm{kDa}$

$74 \mathrm{kDa}$
$85 \mathrm{kDa}$
$74 \mathrm{kDa}$ 


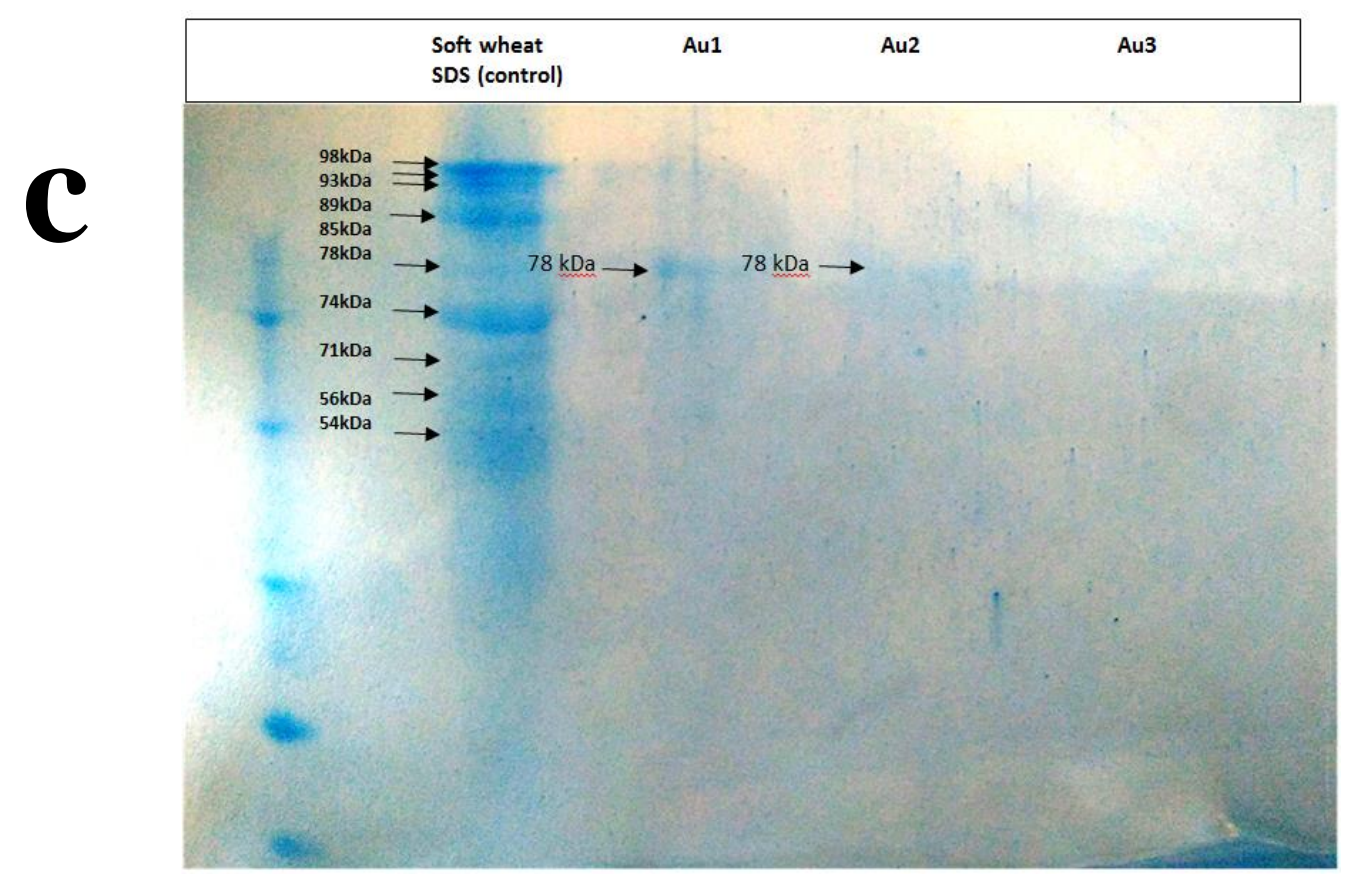

Figure S14. SDS page scans of protein fractions adsorbed on Au NPs for hard (a), medium (b), soft(c) wheat protein with their corresponding controls. Au1, Au2, and Au3 represent $0.25,0.50$, and $1.0 \mathrm{mM}$ gold salt used for the synthesis of Au NPs in the presence of corresponding protein. 


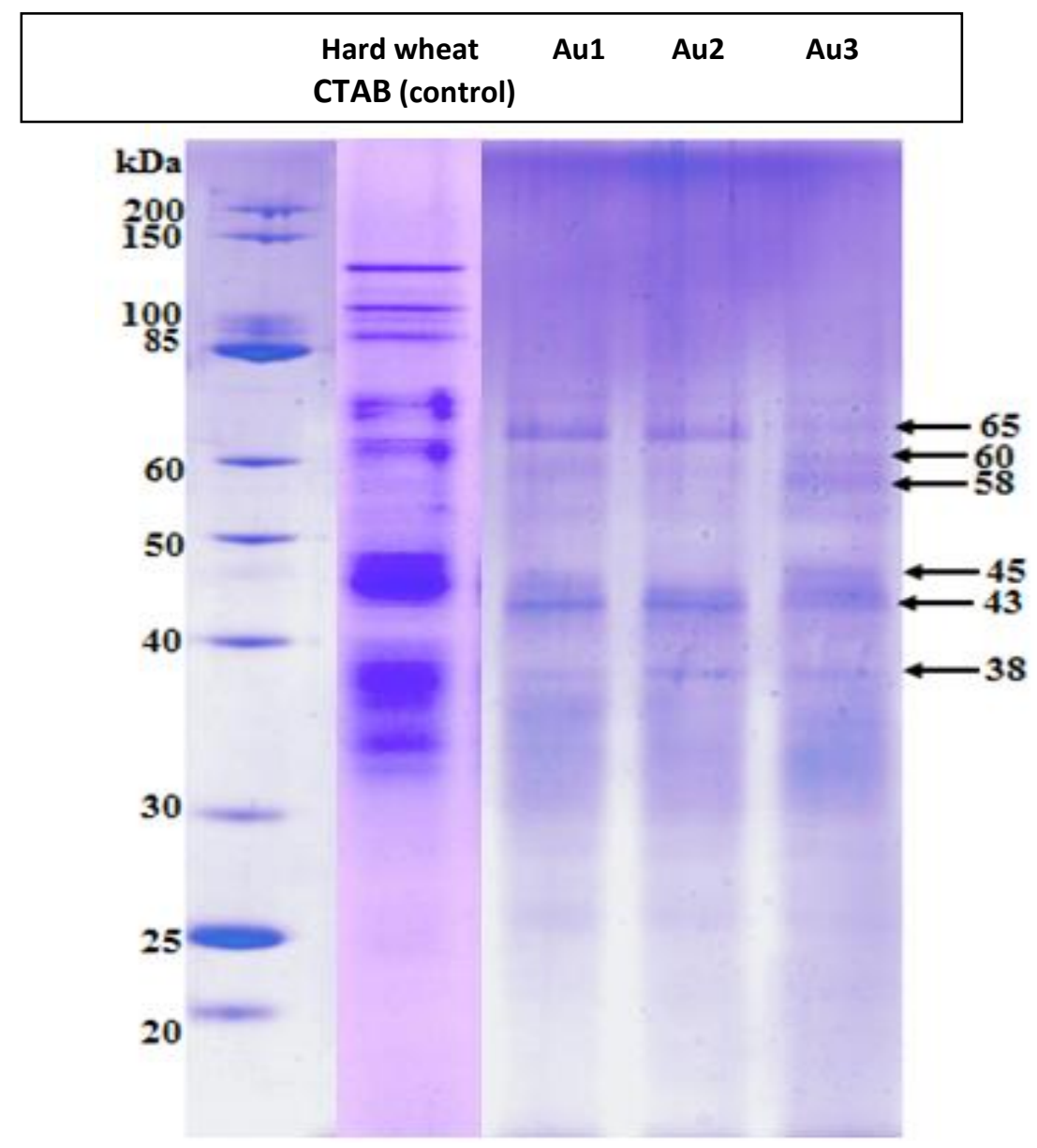

Figure S15. SDS page scan of protein fractions adsorbed on CTAB solubilized hard wheat protein Au NPs with its corresponding control. See details in the text. Au1, Au2, and Au3 represent $0.25,0.50$, and $1.0 \mathrm{mM}$ gold salt used for the synthesis of Au NPs in the presence of corresponding protein. 


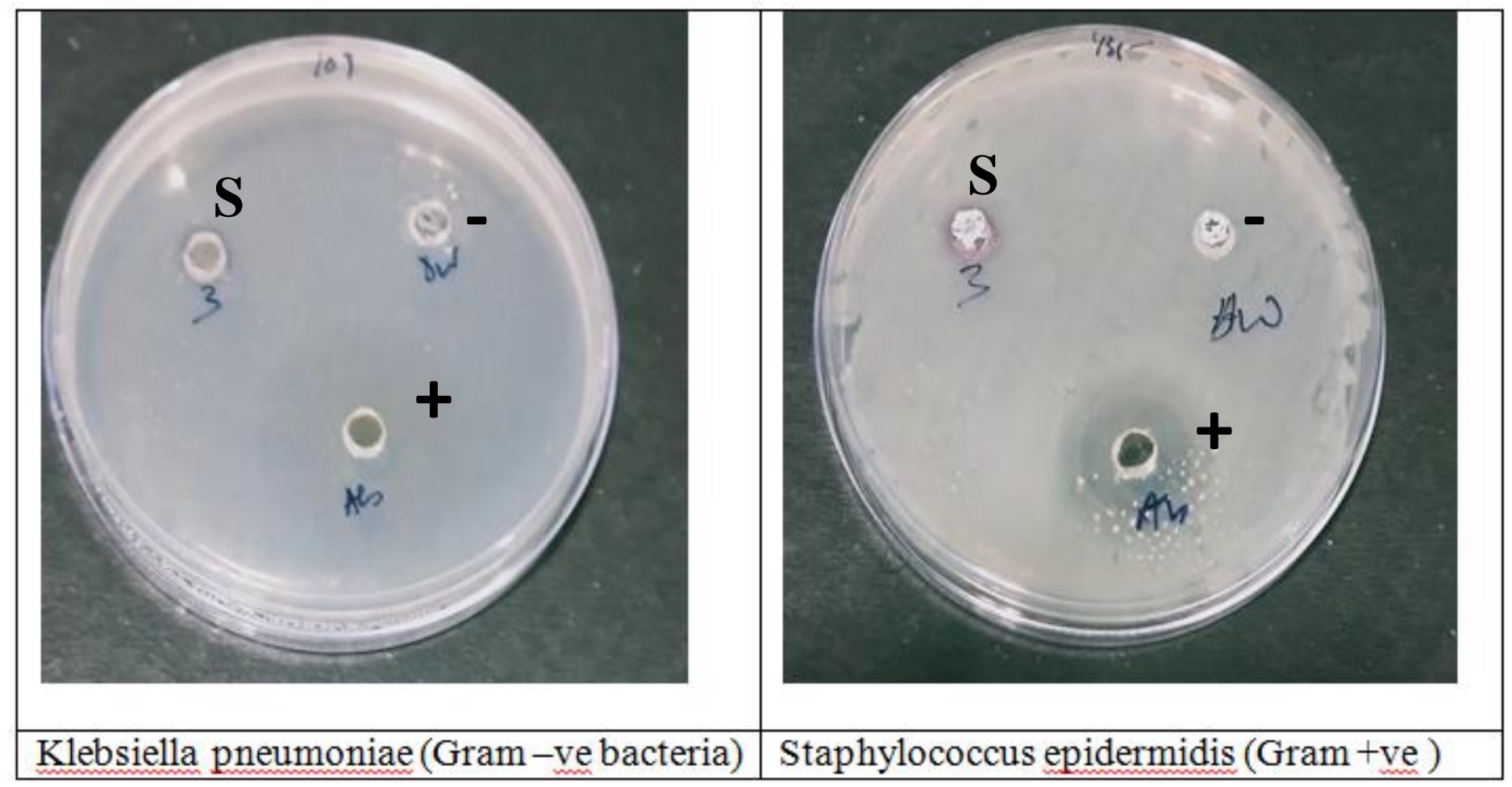

Figure S16. Images of zone of inhibition against Klebsiella pneumonia (A) and zone of inhibition against Staphylococcus epidermidis (B). "_" represent negative control and "+" represent positive control and "S" represent SDS solubilized wheat protein conjugated NPs. See details in the text. 